\title{
Market based instruments: issues and opportunities for agriculture and water quality services in Alberta, Canada
}

\author{
G. L. Kerr ${ }^{1} \&$ H. Bjornlund ${ }^{2,3}$ \\ ${ }^{1}$ University of Calgary, Alberta, Canada \\ ${ }^{2}$ University of Lethbridge, Alberta, Canada \\ ${ }^{3}$ University of South Australia, Australia
}

\begin{abstract}
Society is dependent on healthy ecosystems to supply crucial ecosystem services (ES) for human well-being; including quality source water for drinking, economic use and recreational opportunities. Presently human development activities are threatening many ecosystems and thereby the quality of life of our societies. Market-based instruments (MBIs) are being promoted as a valid tool to help governments manage this complex issues; however not many jurisdictions have much experience with MBIs. This paper investigates the importance of context and values for the acceptance of MBIs. Building on economic theory, we expose how landowners' values and perspectives are important factors in their potential acceptance of MBIs for environmental management. A case study on water quality issues caused by non-point source contaminants in southern Alberta is used to look at land owners values and perspectives. The paper presents key theoretical underpinnings of the research, describes the methods used and preliminary findings are reported. We conclude with the key learnings from the work and the next steps of the overall research program.
\end{abstract}

Keywords: market-based instruments, environmental objectives, water quality, non-point source, agriculture, values and perspectives.

\section{Introduction}

Society is dependent on healthy ecosystems for human well-being; however global trends reveal that most ecosystems are being degraded. Decreased 
ecosystem functions threaten adequate production of ecosystem services, such as clean air and water. Ecosystem Services (ES) has evolved as a metaphor, popularised by the Millennium Ecosystem Assessment, to counteract the degradation of critical ecosystem functions and conditions around the world. By providing a link between human behaviour and ecosystems, this global effort is trying to provide a compelling argument that sustaining ecosystem health links to human quality of life [1].

Most of our present day environmental management problems defy traditional bureaucratic approaches to problem solving because they are 'wicked'; i.e. they are complex, non-linear and contain uncertainty [2]. Traditional solutions, such as uniform standards, lack the flexibility to adapt under these circumstances. Market-based instruments (MBIs) have become more popular within the environmental field as they are flexible and can be more effective and efficient at meeting an objective. The literature is, however, rich in studies of MBIs not delivering on intended objectives.

Economic theory maintains that 'rationale' actors will make decisions based on wealth maximising principles; however experience with MBIs shows that actors do not always behave that way. The extent to which MBIs for the provision of ES will be accepted by actors is not well documented. Exploring and understanding some of these factors requires an interdisciplinary lens.

For any government, developing policy tools requires that they are designed for a specific objective, place and circumstances. As Dr. Helen Ingram puts it, "Prescriptions need to fit context" [3, p. 1]. A critical aspect of designing policy is an understanding of the social context, an aspect that economics has not been able to deal with adequately. Values and perspectives about MBIs may significantly affect the acceptance and therefore success of MBIs [4]. More specifically, this lack of contextual understanding has led to issues, such as a lack of trust and fit $[5,6]$.

This paper presents theoretical underpinnings guiding the research, a description of the case study regions of southern Alberta, the rational and overview of mixed methods employed, preliminary results, analysis and concludes with some key statements on how this paper fits into the overall research project.

\section{Literature}

\subsection{Environmental issues and context}

Most natural resource problems today defy traditional bureaucratic and analytic approaches to problem solving because they are complex, non-linear and contain uncertainty [1]. When designing policies and instruments to resolve environmental issues, such as water quality, they need to be placed into the appropriate context, including an understanding of relevant stakeholders' issues incorporating their input into the solutions. The shift in the understanding of the issues and how to solve them requires a new framework. Mayberry et al. [7] note that in Australia MBIs have "considered landholders to be homogenous", 
therefore missing an important opportunity to tailor the design and implementation of an MBI to increase its acceptance on the ground, and hence the ability to meet the environmental objective. This is a critical area of research in environmental governance across the world.

Context, as a term, is often used to signify the vague, residual, unexplainable, and usually small variations that are not captured in generalized theory. In contrast, context in this paper is used to signify the complex characteristics that distinguish one geographic and temporal place from another. Just as ecologists see the interrelationships among numbers of physical things and living organisms as making up a particular ecology, context signifies the nexus of physical, natural, political, cultural, social, and economic phenomena that make one place distinct from another [3]. The context of a place depends upon: what has happened in the past; the development of some organizations and institutions and not others; and changes in social capital [8].

\subsection{Economic theory}

Economic value reflects human preferences for something usually in monetary terms. Economists argue that most ES can be considered common property rights, or public goods. This leads to them not being fully considered in private decision making and tend to be under-produced [9]. The challenge then is to internalize the benefits of the public goods into private decision making so ecosystems are conserved and an adequate amount of ES is supplied. This has lead to the development and promotions of MBIs for use by governments to expose the value of ES and incent 'rational man' with price signals to adopt desired behaviour or penalties for continuing poor behaviour [10].

Some of the key strengths of MBIs, both theoretically and from case study observations, are that they are more flexible and efficient than traditional tools such as universal standards, and can internalize some of the costs or benefits that are outside the current decision-making context. Another benefit is that they allow each participant to make their own choices about how much they want to engage in an MBI. This decision is based on their privately held information, such as values, perspectives, as well as personal and professional circumstances, such as whether farmers have a succession plans for their farm [11].

Market based instruments have had mixed results around the world. Many have not operated as predicted, which could be linked to the design being based on 'idealized' economic principles and conditions. Additionally the designers may have failed to recognise, or consider i) socio-political factors ii) transaction costs; iii) uncertainty around property rights; or iv) provide appropriate incentives to participate [12]. These are largely unexplored area in understanding how context, values and perspectives influence the behaviour and decisions of individuals and groups that are impacted by, or engaged in MBIs. If these could be teased out adequately there may be more evidence as to what potential buyers and sellers of ecosystem services, and their community, is willing to accept to achieve a societal goal. 


\subsection{Values and perspectives}

Everyone has their own unique way of interpreting the world, such that predicting a human response to a condition or policy is difficult and might vary depending on time and conditions [13]. Values and perspectives are thought to be formulated through social learning or direct experience with the environment. Values are informed by culture, life cycle stage, socio-economics, place, perceptions and feelings. Individuals' values help to form their attitudes and the mental model they apply to understand what they experience [14].

Determining attitudes and values is important as they determine how we interpret and react to various situations and more importantly provide insight into the determinants of our behaviour. Research was undertaken on Australian landowners to establish if landowners can be "differentiated according to the values they place on their landholdings" [7, p.61]. Earlier work within this research program employed the 'Theory of Planned Behaviour' to explore value orientation of landowners with regard to scenarios for payments for ecosystem services benefits [14]. This paper draws from two different methods to look more broadly at some acceptability issues of MBIs for water quality objectives.

Despite the apparent benefits of using market-based instruments, noted earlier, there are few full scale/ non pilot examples in Canada. We argue that proactively differentiating and classifying land holder values and objectives is important from a policy perspective in the design and implementation of MBIs. As Mayberry et al. note, it can be "an important step towards landholder goaltargeting to best induce land stewardship behaviours" [7, p. 63]. Evidence that values and perspectives can play a role in the acceptance of MBIs is supported within a number of papers $[15,16]$.

\section{Alberta as a case study}

Water is critical to all regions of the world. In the southern region of Alberta, water frequently impacts life through floods and drought, issues made more difficult due to the modification of the landscape. There is no one stakeholder group that has had more impact on water than agriculture and no group holds more water licences or owns more private land. We focus on agriculture because of the impacts on water quality and the limited success the Government of Alberta has had on managing non-point source issues.

A number of studies have been done, to understand the state of the aquatic ecosystems. Water quality monitoring in tributaries of the Oldman River has shown total Phosphorous and total Nitrogen concentrations in excess of the Alberta Surface Water Quality Guidelines, and levels of faecal coliforms that occasionally exceed provincial guidelines for contact recreation and irrigation [17]. One study rated 31 of 33 main stem rivers in the SSRB as either 'moderately impacted' to 'degraded' as a consequence of the current level of water extraction [18]. Within this region, agriculture is the largest source of nonpoint source (NPS) inputs into waterways. 
Market-based instruments are being promoted in Alberta to augment traditional governance tools for the management of complex and scientifically uncertain nature of environmental issues. In Alberta a number of policies and legislation has been introduced to enable and encourage the use of MBIs. These include the Water for Life Strategy [19], the Land-Use Framework (LUF) [20], the Alberta Land Stewardship Act (ALSA) [21], and others.

The Alberta government's approach of encouraging MBIs for environmental policy is problematic given the limited experience with MBIs and lack of evidence of their acceptability in Alberta. Ingram reminds us that water management experts have been good at developing replacements to current system flaws; however "History is littered with formulas that were embraced by both scholars and practitioners, but either failed to take hold, or, when implemented, failed to live up to their promise" [3, p.1]. The methods and results section present part of the research program looking at how to overcome some of these failures within the Alberta context.

\section{Methodology and results}

In social science research, a multi method approach using qualitative and quantitative data is recommended to shed light on the perceptions and value orientations of the subject group. The mixed methodology for this paper draws from two different research tools used during the overall research project and due to limitations of the length of the paper; we provide a brief overview of the method, the results obtained and the analysis.

Previous literature has shown that there are many variables that influence landowners' adoption of, or intention to adopt, environmental practices [7]. The two methods employed were a telephone survey in 2010 and semi-structured interviews with key actors in southern Alberta. Both the telephone survey and interviews sought information around MBIs, ecosystem services, and acceptability. The telephone survey was part of a Masters student's thesis. This paper only deals with questions added to the survey for the purpose of this research.

\subsection{Telephone survey}

In 2010 a telephone survey was completed as part of a research program to understand the values and perspectives with regard to MBIS for ES production. This telephone survey was conducted only with landowners who were divided into agricultural producers and non agricultural landowners. This was an attempt to understand the perspectives within each group and the differences and similarities between them. The survey (S) collected 350 responses (17\%) from the Municipal District of Willow Creek and the County of Lethbridge in southern Alberta (See Figure 1). There were 298 respondents who identified as agricultural producers $(\mathrm{P})$ and 52 as non-agricultural land owners $(\mathrm{N})$. The producers were more likely to be male, be raised in a rural setting, be politically conservative, have more children, own land that has been in the family for 


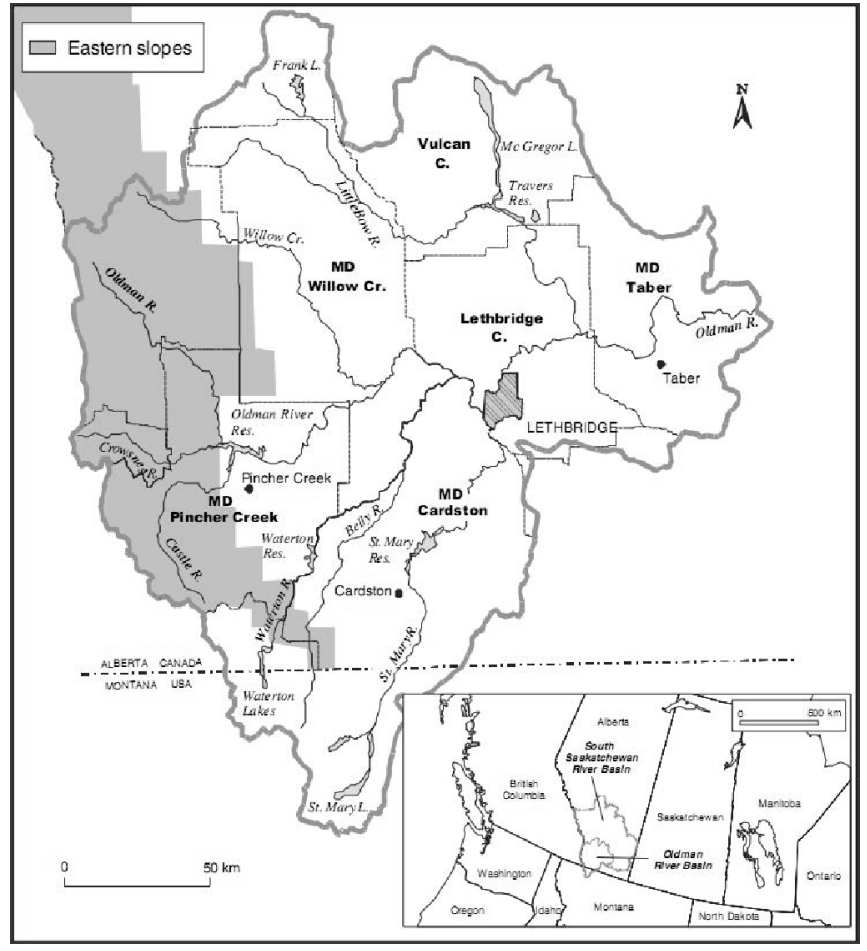

Figure 1: $\quad$ The Oldman River basin, Alberta, Canada [22].

longer, and have a higher expectancy of the land remaining in the family for the next generation [14].

This paper analyses the results of one of the four sections of the survey looking at governance and policy perspectives by asking questions about water quality, ecosystem services, and financial incentives/disincentives and types of MBIs. Tables 1 through 3 present the results of the related survey question groupings.

In Table 1 a first difference between the two land owner groups is that more producers believe water quality issues are well recognised in their area which makes sense as they 'work the land'. Another difference is that producers are more favourable towards using voluntary approaches or market incentive rather than regulation to control water quality, which is perhaps to be expected given the number of external controls over the livelihoods of producers, such as climate and product prices. The other two questions show some consensus, both groups believe that both the government and the landowners should be responsible for water quality, with a stronger emphasis on the responsibility of the landowner. 
Table 1: Water quality opinion statements.

\begin{tabular}{|c|c|c|c|c|c|c|c|c|}
\hline & \multicolumn{7}{|c|}{$\begin{array}{l}\text { Percent of responses for scale of strongly disagree } \\
\text { (1) to strongly agree (7) }\end{array}$} \\
\hline & & 1 & 2 & 3 & 4 & 5 & 6 & 7 \\
\hline \multirow{3}{*}{$\begin{array}{l}\text { B1_1) Water quality issues are } \\
\text { well recognized in your area. }\end{array}$} & $\mathrm{S}$ & 3.7 & 4.3 & 3.4 & 10.0 & 13.1 & 27.1 & 38.3 \\
\hline & $\mathrm{N}$ & 5.8 & 19.2 & 1.9 & 7.7 & 7.7 & 25.0 & 32.7 \\
\hline & $\mathrm{P}$ & 3.4 & 1.7 & 3.7 & 10.4 & 14.1 & 27.5 & 39.3 \\
\hline \multirow{3}{*}{$\begin{array}{l}\text { B1_2) Instead of using regulation } \\
\text { to control water quality, } \\
\text { government should use other } \\
\text { means such as voluntary } \\
\text { approaches or market incentives. }\end{array}$} & $\mathrm{S}$ & 11.4 & 7.7 & 10.0 & 26.0 & 13.7 & 18.3 & 12.9 \\
\hline & $\mathrm{N}$ & 11.5 & 15.4 & 9.6 & 30.8 & 15.4 & 7.7 & 9.6 \\
\hline & $P$ & 11.4 & 6.4 & 10.1 & 25.2 & 13.4 & 20.1 & 13.4 \\
\hline \multirow{3}{*}{$\begin{array}{l}\text { B1_3) The provincial government } \\
\text { should be the entity held } \\
\text { accountable and responsible for } \\
\text { water quality. }\end{array}$} & $\mathrm{S}$ & 5.4 & 8.0 & 6.3 & 21.7 & 20.6 & 19.4 & 18.6 \\
\hline & $\mathrm{N}$ & 3.8 & 9.6 & 3.8 & 26.9 & 13.5 & 9.6 & 32.7 \\
\hline & $\mathrm{P}$ & 5.7 & 7.7 & 6.7 & 20.8 & 21.8 & 21.1 & 16.1 \\
\hline \multirow{3}{*}{$\begin{array}{l}\text { B1_4) Landowners, including } \\
\text { farmers, ranchers, municipalities, } \\
\text { golf courses, first nations, and so } \\
\text { on, should be accountable and } \\
\text { responsible for water quality. }\end{array}$} & $\mathrm{S}$ & .6 & 1.7 & 1.1 & 5.7 & 13.7 & 32.6 & 44.6 \\
\hline & $\mathrm{N}$ & 3.8 & 3.8 & 3.8 & 1.9 & 7.7 & 30.8 & 48.1 \\
\hline & $\mathrm{P}$ & .0 & 1.3 & .7 & 6.4 & 14.8 & 32.9 & 44.0 \\
\hline
\end{tabular}

Note: $\mathrm{S}$ is for total Sample (350 responses), $\mathrm{N}$ is non-agricultural land owner portion (52 responses), and $\mathrm{P}$ is Producer portion (298 respondents). Modified from [14].

Table 2 focused on revealing knowledge and perspectives on ecosystem services. The majority think that their land provides ecosystem services that benefit them and their family. However, non-producers agree slightly more that improving water quality within the County of Lethbridge and the MD of Willow Creek will increase the benefits they receive from their land.

Table 2: $\quad$ Ecosystem services opinion statements.

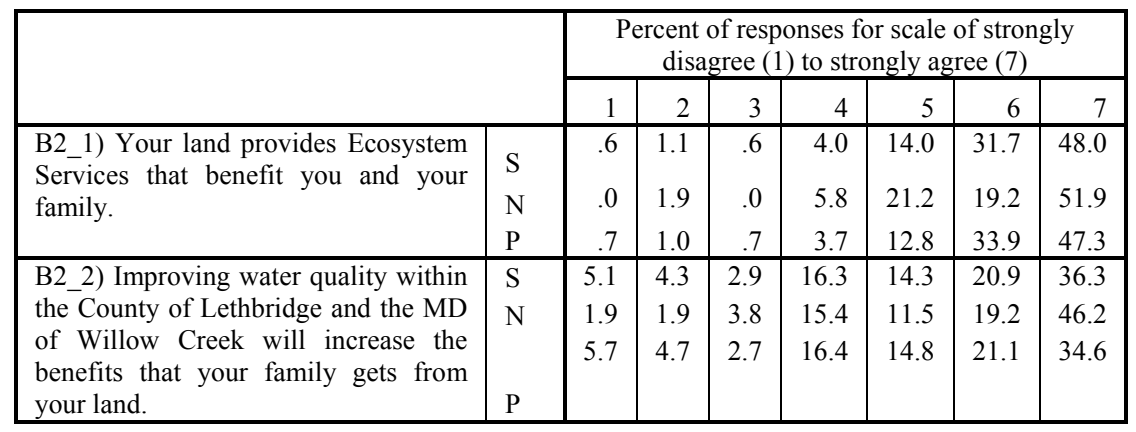

Note: $\mathrm{S}$ is for total Sample (350 responses), $\mathrm{N}$ is non-agricultural land owner portion (52 responses), and P is Producer portion (298 respondents). Modified from [14].

Table 3 presents the results of a variety of likely MBIs that could be used for water quality based on previous research into the water quality issues and interviews with MBI experts. There is a large group of landowners $(30.3 \%)$ that 
are unsure if financial incentives are understood by members of their communities, the opinion of producers and non-producers are similar. Producers are significantly more likely to agree that cost effectiveness is an appropriate reason to use MBIs to improve water quality. Landowners generally agree that

Table 3: $\quad$ Financial incentive/disincentive and MBI opinion statements.

\begin{tabular}{|c|c|c|c|c|c|c|c|c|}
\hline & \multicolumn{7}{|c|}{$\begin{array}{l}\text { Percent of responses for scale of strongly disagree } \\
\text { (1) to strongly agree (7) }\end{array}$} \\
\hline & & 1 & 2 & 3 & 4 & 5 & 6 & 7 \\
\hline $\begin{array}{l}\text { B3_1) The use of financial } \\
\text { incentives to improve water quality } \\
\text { is currently understood by members } \\
\text { of the Municipal District of Willow } \\
\text { Creek and the County of } \\
\text { Lethbridge. }\end{array}$ & $\begin{array}{l}\mathrm{S} \\
\mathrm{N}\end{array}$ & $\begin{array}{l}8.6 \\
7.7 \\
8.7\end{array}$ & $\begin{array}{r}9.4 \\
15.4 \\
8.4\end{array}$ & $\begin{array}{l}12.3 \\
13.5 \\
12.1\end{array}$ & $\begin{array}{l}30.3 \\
30.8 \\
30.2\end{array}$ & $\begin{array}{l}21.4 \\
21.2 \\
21.5\end{array}$ & $\begin{array}{r}12.0 \\
5.8 \\
13.1\end{array}$ & $\begin{array}{l}6.0 \\
5.8 \\
6.0\end{array}$ \\
\hline $\begin{array}{l}\text { B3_2) Cost effectiveness is an } \\
\text { appropriate reason for using } \\
\text { market-based instruments to } \\
\text { improve water quality in this area. }\end{array}$ & $\begin{array}{l}\mathrm{S} \\
\mathrm{N}\end{array}$ & $\begin{array}{l}4.6 \\
7.7 \\
4.0\end{array}$ & $\begin{array}{l}2.9 \\
9.6 \\
1.7\end{array}$ & $\begin{array}{l}7.7 \\
9.6 \\
7.4\end{array}$ & $\begin{array}{l}21.7 \\
23.1 \\
21.5\end{array}$ & $\begin{array}{l}26.6 \\
21.2 \\
27.5\end{array}$ & $\begin{array}{l}24.9 \\
15.4 \\
26.5\end{array}$ & $\begin{array}{l}11.7 \\
13.5 \\
11.4\end{array}$ \\
\hline $\begin{array}{l}\text { B3_3) As fertilizer run-off } \\
\text { contributes to water quality issues } \\
\text { market-based instruments should be } \\
\text { used to provide incentives to } \\
\text { change land management practices } \\
\text { to reduce run-off. }\end{array}$ & $\begin{array}{l}\mathrm{S} \\
\mathrm{N}\end{array}$ & $\begin{array}{l}4.6 \\
1.9 \\
5.0\end{array}$ & $\begin{array}{l}2.6 \\
1.9 \\
2.7\end{array}$ & $\begin{array}{l}4.0 \\
1.9 \\
4.4\end{array}$ & $\begin{array}{l}11.7 \\
11.5 \\
11.7\end{array}$ & $\begin{array}{l}21.7 \\
15.4 \\
22.8\end{array}$ & $\begin{array}{l}31.1 \\
40.4 \\
29.5\end{array}$ & $\begin{array}{l}24.3 \\
26.9 \\
23.8\end{array}$ \\
\hline $\begin{array}{l}\text { B3_4) As buffer zones in specific } \\
\text { areas can help limiting run-off and } \\
\text { thereby improve water quality } \\
\text { market-based instruments should be } \\
\text { used to provide incentives to install } \\
\text { buffer zones. }\end{array}$ & $\begin{array}{l}\mathrm{S} \\
\mathrm{N}\end{array}$ & $\begin{array}{r}2.9 \\
.0 \\
3.4\end{array}$ & $\begin{array}{r}1.1 \\
.0 \\
1.3\end{array}$ & $\begin{array}{r}3.1 \\
.0 \\
3.7\end{array}$ & $\begin{array}{l}8.9 \\
7.7 \\
9.1\end{array}$ & $\begin{array}{l}20.0 \\
23.1 \\
19.5\end{array}$ & $\begin{array}{l}32.3 \\
30.8 \\
32.6\end{array}$ & $\begin{array}{l}31.7 \\
38.5 \\
30.5\end{array}$ \\
\hline $\begin{array}{l}\text { B4_1) As the greater community } \\
\text { benefits from increased water } \\
\text { quality, the gov should pay } \\
\text { landowners to modify their land } \\
\text { management practices to increase } \\
\text { water quality. }\end{array}$ & $\begin{array}{l}\mathrm{S} \\
\mathrm{N}\end{array}$ & $\begin{array}{l}6.6 \\
5.8 \\
6.7\end{array}$ & $\begin{array}{l}6.6 \\
7.7 \\
6.4\end{array}$ & $\begin{array}{r}7.4 \\
11.5 \\
6.7\end{array}$ & $\begin{array}{l}18.6 \\
19.2 \\
18.5\end{array}$ & $\begin{array}{l}21.7 \\
15.4 \\
22.8\end{array}$ & $\begin{array}{l}21.7 \\
26.9 \\
20.8\end{array}$ & $\begin{array}{l}17.4 \\
13.5 \\
18.1\end{array}$ \\
\hline $\begin{array}{l}\text { B4_2) Land use regulations should } \\
\text { be changed so that landowners with } \\
\text { good conservation practices that } \\
\text { benefit water quality are provided } \\
\text { incentives and those with poor } \\
\text { practices are penalised. }\end{array}$ & $\begin{array}{l}\mathrm{S} \\
\mathrm{N}\end{array}$ & $\begin{array}{r}2.6 \\
.0 \\
3.0\end{array}$ & $\begin{array}{l}2.9 \\
1.9 \\
3.0\end{array}$ & $\begin{array}{l}4.3 \\
1.9 \\
4.7\end{array}$ & $\begin{array}{l}8.9 \\
5.8 \\
9.4\end{array}$ & $\begin{array}{l}18.0 \\
19.2 \\
17.8\end{array}$ & $\begin{array}{l}27.7 \\
32.7 \\
26.8\end{array}$ & $\begin{array}{l}35.7 \\
38.5 \\
35.2\end{array}$ \\
\hline $\begin{array}{l}\text { B4_3) The use of substances that } \\
\text { are proven to degrade water quality } \\
\text { should be limited. You would only } \\
\text { agree if the landowners who reduce } \\
\text { the use of these substances can earn } \\
\text { a credit. }\end{array}$ & $\begin{array}{l}\mathrm{S} \\
\mathrm{N}\end{array}$ & $\begin{array}{l}15.1 \\
11.5 \\
15.8\end{array}$ & $\begin{array}{r}10.9 \\
9.6 \\
11.1\end{array}$ & $\begin{array}{l}11.7 \\
11.5 \\
11.7\end{array}$ & $\begin{array}{l}21.7 \\
25.0 \\
21.1\end{array}$ & $\begin{array}{l}21.7 \\
23.1 \\
21.5\end{array}$ & $\begin{array}{r}1.4 \\
9.6 \\
11.7\end{array}$ & $\begin{array}{l}7.4 \\
9.6 \\
7.0\end{array}$ \\
\hline
\end{tabular}

Note: $\mathrm{S}$ is for total Sample (350 responses), $\mathrm{N}$ is non-agricultural land owner portion (52 responses), and P is Producer portion (298 respondents). Modified from [14]. 
MBIs should be used to reduce run-off. Although both groups generally agreed with the statement, non-producers agreed more strongly. Landowners also generally agreed with the government providing payments for modifying land practices and that a financial reward/penalty program should be used; however, non-producers are more likely to agree with B4_2. Finally there is a wide range of opinions on the use of a credit system, with $2 \overline{1} .7 \%$ being unsure or undecided.

\subsection{Interviews}

The telephone survey was followed by semi-structured interviews with local experts and stakeholders. In total, 26 semi-structured interviews were completed in 2011 with subject matters experts and local stakeholders from the City of Lethbridge, Municipal District of Willow Creek and the County of Lethbridge in southern Alberta. Using Nvivo and a transcript by transcript review by the author, the following three themes were revealed, understanding of water quality issues, the involvement of government and use of MBIs. The following are some key findings that help to build a story upon the results of the telephone survey. While the interviews where done with all key stakeholders this paper focuses mostly on the land owners' perspectives; however some critical common results across all participants are also presented as they reveal some of the culture in the south.

All interviewees described southern Alberta, or specifically their area within Willow Creek or County of Lethbridge as a great place to live and there was significant pride in rural living. One of the highlighted terms was around 'part of the rural culture and fabric'. Other interviewees, farmers and non-farmers, noted that most farmers in the area act based on more than simply a purely economic motivation. While a farm is a business there are a number of other reasons why farm families are committed to 'the business'.

When it came to water quality issues most interviewees listed manure as one of the largest agricultural water quality contributor, either from intensive livestock operations or from watering of livestock in or near a water body. A few interviewees, including two that lives in the City of Lethbridge, noted that urban residences perhaps have more of a water quality impact with what gets flushed down the drain and put on their lawns. "The 'urbans' are disconnected from their connection to the environment ... they look at 'rurals' as the problem without the slightest clue of their own impact."

In looking at the role of the provincial government dealing with issues like water quality there were some strong opinions about a lack of trust and expressed scepticism with Alberta government programs. "those guys in Edmonton don't know what works here". "Command and control does not work as there is not enough enforcement and in general, Canadian cultural norms are not to report infractions."

For the landowners interviewed and almost all the other interviewees there is a belief that those on the land try their best. Farmers are recognized as understanding how the land works and being good stewards and the 'original stewards'; however both agricultural and non-agricultural landowners and some of the other interviewees noted that agriculture is an industry that is influenced 
significantly by outside factors such as fertiliser, crop and livestock prices. The economic 'wiggle room' for farmers are sometime quite limited.

There was a general openness to MBIs as a potential tool, but there was also a hesitance that incentives are misunderstood and MBIs present uncertainty and potentially raise serious issues within the community. There was also a statement that there is a "latent and unfulfilled demand to know how landscape work".

\section{Analysis and conclusions}

Governments are struggling with today's wicked environmental management issues. Market-based instruments are being experimented with as an additional governance tool. Economic theory presents actors as 'rationale' in their approach to decision making; however social context, values and perspectives are important and this paper adds to the literature that rationality is not the only concept employed by landowners when considering MBIs.

The results from both the telephone survey and interviews show that landowners have pride in their land and lifestyle. This is not new; however further understanding what this sense of place means from an environmental management perspective may provide important concepts to embed in the design of an MBI. For example, if agricultural actors are considered the 'original stewards' then an MBI might incorporate this and build the financial incentive for increased conservation or changes for a public good. Given the culture of southern Alberta this may be much more effective than a punitive tax, or penalty that insults their current stewardship role.

The survey and interviews both showed an interest in and openness towards using MBIs for ES purposes; however there is a lack of knowledge of and experience with them. One suggestion is to work with the key stakeholders in building an MBI and then testing or piloting it. This may ease the fears around these tools and also serve to educate land owners in a low risk manner may be best.

The results also show some distinctions in perceptions on the actual problem; in this case degradation of water quality and who is responsible for managing the issues. The survey results suggest that producers are more likely to think that water quality is a well recognized issue in their area. As producers may deal more with irrigations and rain runoff issues, it makes sense that they are more aware of the issues facing the region. Therefore when developing an MBI for water quality targeting producers to change their behaviour may require less on education and more need to express the issue in a way so that producers can see they are contributing to the solution, and without being picked on as being the bad players.

Based on our preliminary results, it is proposed that building an understanding of the values and perspectives of landowners is an important policy consideration, prior to design of an MBI. In this example, taking landowners considerations into account may lead to a more contextually sound MBI for water quality that landowners and the community might accept more readily. This provides a good first step towards the goal of MBI acceptance. 
While the telephone survey noted differences between agricultural and nonagricultural landowners, the semi-structured interviews revealed that there is further variability within these two generic groups of actors and with other stakeholders. Q methodology is being employed for the next part of the research to reveal value orientations across all stakeholder groups around the acceptance of MBIs and to look for areas of convergence and divergence is the results that may provide specific considerations for an MBI for non point source water quality in southern Alberta.

\section{Acknowledgements}

Funding for this research has been partially provided by the Canadian Water Network and Alberta Innovates. We would also like to thank Kyle Howard, a master's student who designed the telephone survey to which we added the governance and policy questions for this paper.

\section{References}

[1] Millennium Ecosystem Assessment, Ecosystems and Human Well-being: Wetlands and Water Synthesis. Millennium Ecosystem Assessment Series. Island Press Publications: Washington, D.C, 2005.

[2] Folke, C., Carpenter, S., Walker, B., Schffer, M., Elmqvist, T., Gunderson, L., and Holling, C.S. Regime Shifts, Resilience and Biodiversity in Ecosystem Management. Annual Review of Ecological Evolution Systems 35, pp. 557-81, 2004.

[3] Ingram, $H$. , Water as a multi-dimensional value: implications for participation and transparency. International Environmental Agreements. 6(420), p 1, 2006.

[4] Ostrom, E. Sustainable development of common-pool resources. Environment: Science and Policy for Sustainable Development. 2008.

[5] Bjornlund, H., Efficient water market mechanisms to cope with water scarcity. International Journal of Water Resources Development. 19(4), pp. 553-567. 2003.

[6] Poirier, Assessing Institutions For Aquatic Ecosystem Protection: A Case Study Of The Oldman River Basin, Alberta. Doctorate of Philosophy Thesis. 2008.

[7] Mayberry, D., Crase, L. and Gullifer, C., Categorising farming values as economic, conservation and lifestyle. Journal of Economic Psychology, 26(1), pp. 59-72, 2005.

[8] Tabera, J. David and Akgun Ilhan. Culture as Trigger for Sustainability Transition in the Water Domain: The Matisse Project and the Ebro River Basin. Paper presented at the 5th Iberian Congress on Water Management and Planning. Faro Portugal December 4-8, 2006.

[9] Ostrom, E. Background on the Institutional Analysis and Development Framework The Policy Studies Journal. 39 (1), pp. 7-27. 2011. 
[10] Anderson, J., Gomez W., C., McCarney, G., Adamowicz, W., Chalifour, N., Weber, M., Elgie, S., and Howlett, M., Ecosystem service valuation, market-based instruments and sustainable forest management: a primer. State of Knowledge primer. Sustainable Forest Management Network, Edmonton, Alberta. 2010.

[11] Coggan, A., Whitten, S.M., and Langston, 2005. Nesting MBIs in current institutions and structures - can it be done and what are the implications? CSIRO Sustainable Ecosystems. 2005.

[12] Hockenstein, J.B., Stavins, R.N. and Whitehead, B.W., Crafting the next generation of market-based environmental tools. Environment, 39(4), pp. 12-33, 1997.

[13] North, D.C., The New Institutional Economics and Development. Washington University, St. Louis. Retrieved at qed.econ.queensu.ca /pub/faculty/lloyd-ellis/econ835/readings/north.pdf, 1991.

[14] Howard, K.; Bjornlund, H.; Xu, W. Provision of Ecosystem Services - a study of landowners' values and attitudes and their perceptions of the use of market based instruments. SAREC Report 2011-01, 2011.

[15] Vugteveen, P, Lenders, J.R., Stakeholder Value Orientations in Water Management. Society and Natural Resources, 23(1), p.3, 2010.

[16] Kuehne. G. and Bjornlund, H. (2010): Non-profit maximizing values and attitudes influencing irrigators' management response to new policy instruments. Chapter 6 in Bjornlund, H. Ed. Incentives and instruments for Sustainable Irrigation, WIT Press, 71-85.

[17] Rock, L. and Mayer, B., Isotopic Assessment of Sources of Surface Water Nitrate within the Oldman River Basin, Southern Alberta, Canada. Water, Air \& Soil Pollution: Focus, 4(2/3), pp. 545-562, 2004.

[18] Alberta Environment, Approved Water Management Plan for the South Saskatchewan River Basin in Alberta. Edmonton: Alberta Environment, 2006.

[19] Alberta Environment, Alberta Water for Life: Strategy for Sustainability. Online http://www.waterforlife.gov.ab.ca/docs/strategyNov03.pdf

[20] Alberta Government. Alberta Land-use Framework. Online. http://www.landuse.alberta.ca/AboutLanduseFramework/Default.aspx

[21] Alberta Government. Alberta Land Stewardship Act (ALSA). Online http://www.landuse.alberta.ca/AlbertaLandStewardshipAct/Default.aspx

[22] Ivey, J.L., de Loë, R., Kreutzwiser, R. and Ferreyra, C., An institutional perspective on local capacity for source water protection. Geoforum, 37(6), pp. 944-957, 2006. 